\title{
The United Kingdom Foundation Programme Application: Does Current Literature Unfairly Criticize It?
}

This article was published in the following Dove Press journal: Advances in Medical Education and Practice

\section{Ali Abdall-Razak (iD) \\ Riddhi Shenoy}

Imperial College School of Medicine, London SW7 2AZ, UK
Correspondence: Ali Abdall-Razak Tel +4479201 400I

Email ali.abdall-razak@outlook.com
The application to the United Kingdom foundation programme (UKFP) is a generally uncompetitive process. Across the country, there are 20 foundation schools that a graduate can rank, in order of their preference. Each foundation school will have a specific number of positions available and, depending on a variety of reasons, will receive different levels of application of a first-preference basis. Overall, across the 20 schools, 6998 positions were advertised in 2019, with 7421 first-preference applications made - putting the overall competition ratio at 1.06 applications per position. ${ }^{1} \mathrm{Of}$ course, while some foundation schools, such as West Midlands North (which received just 117 first-preference applications to its 252 positions) are entirely uncompetitive, others, such as the North Central and East London foundation school (which received 672 first-preference applications to its 337 positions) are far more competitive.

The current application to the UKFP involves scoring a graduate out of 100. 50 of these points will arise from a situational judgement test (SJT), sat in the final year of university; the other 50 points will arise from an educational performance measure (EPM). Both aspects of the application, the SJT and the EPM, have received criticism in recent literature. ${ }^{2,3}$ There is a perceived unfairness amongst medical students and graduates on the SJT exam and the EPM calculation. While the SJT is seen as unclear and inconsistent in its opinion on "appropriate" responses, the EPM is accused of being variable, and unstandardized across the UK. However, deeper analysis of published statistics regarding the SJT and the UKFP application suggests these perceived imbalances are not very impactful on the application at all.

Firstly, while it is true that the SJT has been shown to cause a difference in opinion, studies show that contention rests mainly in choosing the most appropriate response to a situation, and not the most inappropriate response. ${ }^{2,4}$ Also, the SJT is known to be an exam where success depends less on bookwork, but on appreciation for interdisciplinary relationships, and behavioural tendencies. It aims to assess more gradual development of professionalism over the student's education, garnered through active participation and attendance. Therefore, while some suggest the SJT represents just a snapshot of the student's ability, its dependence on gradual growth suggests the opposite. ${ }^{2}$ The SJT is a reasonably accurate assessment of one's personal and professional development and motivates students to understand the General Medical Council (GMC) Code of Conduct, and its application. Regardless, 
reports show that graduates perform well in the exam, with averages in 2019 resting between 38.5 and 41.7 out of $50 .^{5}$

Secondly, the EPM score has also been criticized for its variability. ${ }^{6}$ While much of the EPM is based on the applicant's academic performance, some literature unfairly implies a much larger variation than reality. ${ }^{3}$ Every medical student in the country will receive 34 points for their degree; up to 9 extra points are available, based on the decile ranking of the student. In a mostly uncompetitive application programme, these 9 points will matter only in the more competitive foundation schools.

Nevertheless, not only does this decile-dependent scoring pose issues because of a lack of standardization, medical schools are also autonomous in deciding which of the years of the MBBS degree count towards it. For example, at Imperial College London, only years 3 and 4 of the MBBS contribute, while at Bart's and the London, each of the 5 years carry weight towards this ranking. This discrepancy compounds the variability in testing formats and curriculums set by the universities. Still, despite this, over $90 \%$ of graduates achieve one of their top 5 preferences for their foundation school. ${ }^{5}$ While this percentage alone does not justify a variable application, it does show that very few are disadvantaged by it, if at all. It is also important to note that while medical degrees can be of differing lengths (4 or 6 years), all degrees have 3 clinical years, which carry the heaviest weighting for the EPM unanimously, and are the greatest contributors to the SJT score.

Lastly, it should also be mentioned that changes are being made to the UKFP application. The GMC are introducing a compulsory, centrally-set and nationally standardized Medical Licensing Assessment (MLA) for all medical students from the year $2024 .^{6}$ It will consist of an applied knowledge test, and a clinical and professional skills assessment. The introduction of a standardized assessment is an encouraging step by the GMC towards regulating UKFP applications, and potentially creating a UK version of the USMLE.

\section{Disclosure}

The authors report no conflicts of interest in this work.

\section{References}

1. Foundationprogramme.nhs.uk [Internet]. 2019 [cited August 19, 2019]. Available from: http://www.foundationprogramme.nhs.uk/ sites/default/files/2018-12/UKFP\%202019\%20Application\%20Status \%20Report.pdf. Accessed November 25, 2019.

2. Ismail $\mathrm{J}$, Patel $\mathrm{AB}$. Is the situational judgment test a fair way of assessing candidates applying to the United Kingdom Foundation Programme? Adv Med Educ Pract. 2019;10:413-414. doi:10.2147/ amep.s 186536

3. Miah S, Boxall NE, Lamb BW. Is the educational performance measure a fair way of assessing candidates applying to the United Kingdom Foundation Programme? [Letter]. Adv Med Educ Pract. 2019;10:591-592. doi:10.2147/amep.s221821

4. Leng WED, Stegers-Jager KM, Born MP, Themmen APN. Integrity situational judgement test for medical school selection: judging 'what to do' versus 'what not to do'. Med Educ. 2018;52(4):427-437. doi: $10.1111 /$ medu. 13498

5. Foundation Programme UK. 2019 Recruitment stats and facts report [Internet]. Available from: https://www.foundationprogramme.nhs.uk/ sites/default/files/2019-09/2019\%20Recruitment $\% 20$ Stats\%20and\% 20Facts\%20Report.pdf. Accessed August 13, 2019.

6. GMC. The Medical Licensing Assessment [Internet]. Available from: https://www.gmc-uk.org/education/standards-guidance-and-curricula /projects/medical-licensing-assessment. Accessed August 13, 2019.
Advances in Medical Education and Practice

\section{Publish your work in this journal}

Advances in Medical Education and Practice is an international, peerreviewed, open access journal that aims to present and publish research on Medical Education covering medical, dental, nursing and allied health care professional education. The journal covers undergraduate education, postgraduate training and continuing medical education including emerging trends and innovative models linking education, research, and health care services. The manuscript management system is completely online and includes a very quick and fair peer-review system. Visit http://www.dovepress.com/testimonials.php to read real quotes from published authors. 